\title{
ИСТОРИКО-ПРАВОВЫЕ ИССЛЕДОВАНИЯ
}

\author{
HISTORICAL AND LEGAL STUDIES
}

DOI: $10.22363 / 2313-2337-2019-23-4-602-621$

Научная статья

\section{ПРАВОВЫЕ РЕАЛИИ МОНГОЛИИ XVIII - 1-Й ПОЛ. XIX В. ГЛАЗАМИ РОССИЙСКИХ ПУТЕШЕСТВЕННИКОВ (ОПЫТ ЮРИДИКО-АНТРОПОЛОГИЧЕСКОГО АНАЛИЗА)}

\author{
Р.Ю. Почекаев ${ }^{1}$ \\ Национальный исследовательский университет «Высшая школа экономики» \\ 198099, Санкт-Петербург, Россия, ул. Промышленная, д. 17
}

Записки путешественников чаще всего привлекаются исследователями как источник по истории, социально-экономическим отношениям, а также антропологии и этнографии стран и народов, которые посетили авторы. В гораздо меньшей степени этот вид источников использовался историками права, поскольку в большинстве своем путешественники не ставили своей целью описание права посещенных ими стран, и такие сведения в их записках носят, как правило, отрывочный характер. Между тем анализ сведений путешественников о правовом состоянии посещенных стран и народов представляет значительную ценность, поскольку они отражают именно реально существовавшие правовые отношения - в отличие от «идеализированных» правовых реконструкций, которые создаются исследователями на основе сохранившихся юридических памятников соответствующих стран и народов.

В статье предпринимается попытка продемонстрировать ценность записок путешественников как важного и ценного источника по истории права традиционных народов на примере анализа сведений российских путешественников о правовых реалиях Монголии XVIII первой половины XIX в. Предлагается изучение соответствующих текстов с точки зрения юридической антропологии.

Теоретическую основу исследования составили труды антропологов права (Н. Рулан, А.И. Ковлер, В.В. Бочаров), которые значительное внимание уделяют именно правовому развитию стран и народов, относящихся к традиционной правовой семье. Источниковая база исследования представлена записками российских путешественников, с разными целями посетившими

1 (С) Почекаев Р.Ю., 2019.

This work is licensed under a Creative Commons Attribution 4.0 International License https://creativecommons.org/licenses/by/4.0 
Монголию в XVIII - первой половине XIX в. - дипломатов, торговцев, миссионеров и военных разведчиков - в записках которых (включая официальные отчеты, дневники, сочинения, составленные по итогам поездок) имеются сведения, касающиеся правовых отношений в Монголии рассматриваемого периода. В качестве методов исследования используются формальноюридический, историко-правовой, сравнительно-правовой, системный анализ, структурнофункциональный метод.

Записки русских путешественников исследуются как источник сведений о правовой ситуации и отношении монголов к своему традиционному и маньчжурскому имперскому праву в меняющихся политических и социально-экономических условиях. Анализируются позиции и подходы самих авторов записок к изучению монгольских правовых реалий: интерес к конкретным юридическим аспектам, оценка их с точки зрения представителей другой правовой культуры и т.д.

Автор приходит к выводу, что записки путешественников о монгольском праве являются ценным источником как о процессе правового развития монголов (их правоотношений и правосознания), так и о формировании отечественной традиции изучения права традиционных народов и государств, т.е., по сути, начального (практико-ориентированного) этапа российской юридической антропологии.

Ключевые слова: традиционное право кочевых народов, юридическая антропология, записки путешественников, Монголия XVIII-XIX вв., Цинская империя

Информация о финансировании. Исследование выполнено за счет гранта Российского научного фонда (проект № 19-18-00162), реализуемого в Институте языков и культур имени Льва Толстого.

\section{ВВЕДЕНИЕ}

Период XVIII - 1-й пол. XIX в. стал переломным в правовом развитии Монголии. К концу XVII в. практически вся Монголия вошла в состав империи Цин, и следующие полтора столетия стали периодом ее интеграции в маньчжурское политико-правовое пространство. Формально маньчжурские власти продолжали проводить политику «сбережения сил монгольского народа», фактически же они старались уменьшать автономию монгольской знати, урезать число налоговых льгот и привилегий для монголов и всячески изолировать их от внешних контактов, все больше распространить на них маньчжурское законодательство, постепенно превращая их из вассалов в подданных (Butler, 1982:4; Heuschert-Laage, 2014:650; Popov, 2015). Во многом это оказалось связано с тем, что в 1758-1759 гг. Цинская империя разгромила и присоединила западно-монгольское Джунгарское ханство, в противостоянии с которым монгольская конница постоянно задействовалась с конца XVII в.

Ценнейшие сведения по истории Монголии содержатся в записках российских путешественников, посетивших империю Цин и непосредственно монгольские кочевья в рассматриваемый период. Эти источники неоднократно привлекались специалистами по истории Монголии и русско-монгольских отношений. Однако их сведения, касающиеся монгольского права и правоотношений до сих пор, насколько нам известно, не исследовались. Соответственно, в данной статье предпринимается попытка анализа этих сведений с позиций юридической антропологии. Записки путешественников выступят, во-первых, как источник сведений о монгольском праве и его практическом применении, 
особенностях монгольского правосознания и отношения к праву, поскольку путешественники отражали в своих записках те отношения, которые наблюдали, а нередко и становились их непосредственными участниками. Во-вторых, представляет интерес и анализ позиции самих авторов записок: какие именно аспекты правового развития монголов их интересовали, как они оценивали уровень этого развития, принципы и конкретные нормы права. Таким образом, записки путешественников для нас одновременно являются и источником знаний о «правогенезе» монголов рассматриваемого периода и в какой-то степени об одном из ранних этапов в становлении отечественной юридической антропологии с ее особыми методами и подходами, проявившимися в сборе и анализе информации о правовых реалиях кочевников Восточной Азии.

В XVIII - 1-й пол. XIX вв. большое количество российских дипломатов посетило империю Цин с различными целями. Следуя в Пекин, они проезжали через кочевья монголов и имели возможность наблюдать различные стороны из жизни монголов, включая и правовые отношения. Среди них - посол С.Л. Владиславич-Рагузинский, подписавший в 1727 г. Кяхтинский мирный договор с империей Цин, военные курьеры секунд-майор И.В. Якоби, советник В.Ф. Братищев, капитан-поручик И.И. Кропотов, поручик А. Незнаев, В. Гаупт и др. В то же время XVIII в. стал временем начала научного изучения восточных владений Российской империи и соседних государств. Соответственно, Монголией и ее обитателями интересовались также ученые, среди которых были академики И.Г. Георги, И.П. Фальк, П.С. Паллас и др., побывавшие в регионе в начале 1770-х гг.

В 1-й пол. XIX в. наряду с дипломатами и учеными правовые реалии монголов описывали также сотрудники российских духовных миссий в Китае, которые впоследствии также стали известны как выдающиеся востоковеды. В рамках данного исследования представляют интерес сочинения дипломата Е.Ф. Тимковского, выдающегося отечественного востоковеда Н.Я. Бичурина (о. Иакинф), монголоведа О.М. Ковалевского и синолога П.И. Кафарова (о. Палладий). Таким образом, в нашем распоряжении имеется довольно значительный корпус источников, позволяющих сформировать определенное представление об особенностях правового развития монгольских народов в XVIII - 1-й пол. XIX в., их правовых воззрениях, а также проанализировать отношение самих авторов к уровню правового развития монголов и отдельным аспектам правоотношений.

\section{ПРАВОВОЕ ПОЛОЖЕНИЕ МОНГОЛЬСКОЙ ЭЛИТЫ}

Представляют интерес в записках русских дипломатов, проезжавших через Монголию (Халху) в Китай, сообщения о статусе монгольских правителей, нашедшем отражение в их контактах с представителями Российской империи. Следует отметить, что в первые десятилетия XVIII в. российские власти и их дипломатические представители «по инерции» продолжали пытаться всту- 
пать в отношения с монгольскими правителями, как они это делали в XVII в., до вхождения Монголии в состав империи Цин ${ }^{2}$. Им даже выделялись средства и подарки для вручения не только китайским, но и монгольским правителям и чиновникам (Bereznitsky, 2017:58). Однако очень скоро дипломаты убедились, что монгольские правители выполняют исключительно волю цинских властей, не позволяя себе ни малейшего проявления самостоятельности.

Так, русские послы и другие дипломатические представители неоднократно упоминают, что те отказывались пропускать их через свои владения, задерживая до получения указаний от маньчжурских властей (Tikhvinskii, 1978:303; Demidova, Myasnikov, 1990:385). Причинами являлись либо проблемы, связанные с монгольскими перебежчиками, которых русские пограничные власти отказывались выдавать, либо разного рода торговые споры и пограничные стычки (Andrievich, 1887:132). Монгольские феодалы могли самостоятельно участвовать только в решении мелких локальных вопросов. Например, в сентябре 1720 г. из Красноярска был направлен к «мунгальскому владельцу Гунбеку» сын боярский Т. Ермолаев, чтобы потребовать возвращения бежавших к тому русско-подданных «ясачных иноземцев». Вскоре выяснилось, что те бежали, напуганные слухом, что их собираются насильно крестить, и вопрос о возвращении был решен без вмешательства маньчжурских чиновников (Timofeev, 1885:279-281).

Более активно проявляли себя лишь те представители монгольской знати, которые сами находились на маньчжурской службе. Например, П.С. Паллас пишет, что переговоры с российскими пограничными властями по поводу возврата перебежчиков вел монгольский тайджи, который носил маньчжурский ранг «бошко» и, как и трое его подчиненных, обладал цинскими символами отличия, что позволяло ему вести себя более решительно и самостоятельно в переговоpax с русскими (Pallas, 1788:215-216).

В начале XVIII в. формальным главой Монголии, как сообщает С. Рагузинский, в 1720-е гг. считался Тушету-хан, которому «все здешния дела его богдыханово величество определил по старому предусмотрению» (Demidova, Myasnikov, 1990:397). Не изменилась ситуация и к началу 1750-х гг.: И.В. Якоби также сообщает, что наместником империи Цин в Монголии по-прежнему являлся Тушету-хан (Bereznitsky, 2017:153-154). И когда российские дипломаты, уже имевшие возможность разобраться в том, кто фактически контролирует ситуацию в Монголии, просили назначать для решения пограничных и иных дипломатических споров маньчжурских чиновников, цинские власти каждый раз заявляли, что эти вопросы находятся в ведении монгольских князей (Demidova, Myasnikov, 1990:397) — прекрасно понимая, что те все равно дождутся

\footnotetext{
2 Так, например, посол в Китай Л. Измайлов в 1720 г. отправил своего представителя унтер-офицера Засекина к Тушету-хану, ожидая, что тот окажет посланцу «подобающий прием» (Andrievich, 1887:128).
} 
распоряжений из Пекина. А уже в 1750-1760-е гг. в Урге появляются полномочные представители маньчжурских императоров - амбани, носившие титулы ванов: именно они вели переговоры с российскими дипломатами при их проезде через Монголию, тогда как монгольские имели такое право лишь в случае отсутствия амбаня в столице (Myasnikov, Sarkisova, 2011:291, 323; Heuschert-Laage, 2014:651).

Еще одной важной тенденцией в рассматриваемый период стала активная интеграция представителей монгольской правящей элиты в сановную иерархию империи Цин. Наибольшими правами и привилегиями пользовались те потомки Чингис-хана, которые получали от маньчжурских сюзеренов титулы пяти степеней цин-ван, цзюнь-ван, бэйлэ, бэйсэ и гун; по статусу ханы аймаков (т.е. самые высшие правители в Монголии анализируемого периода) приравнивались к цин-ванам (Zhang, 2017:134). Кроме того, монгольские владетельные князья, не имевшие маньчжурских титулов и званий, по своим правам и привилегиям были ниже обладавших таковыми, даже если имели большие уделы (Bichurin, 1828:162-163). Титулы и звания переходили по принципу первородства (майората), но при этом наследник вступал в права лишь после издания соответствующего указа императора по представлению Палаты внешних сношений (Bichurin, 1828:163-164; Elverskog, 2006:72). Возраст наследника при этом не служил препятствием для получения титула или вступления в должность: если новый владетельный князь (дзазсак) был слишком молод, фактическая власть до его совершеннолетия осуществлялась его помощником - туслагчи (Timkovskiy, 1824:90). Соответственно, представители маньчжурской администрации в Монголии, амбани, в этот период в большей степени ограничивались надзорными функциями, тогда как административные принадлежали именно монгольским князьям-дзасакам и их чиновникам (Haupt, 1858:62-63, 78).

Неудивительно, что многие монгольские чиновники вели себя по отношению к российским путешественникам весьма высокомерно, позиционируя себя в качестве представителей властей империи Цин. Е.Ф. Тимковский вспоминает, как один туслагчи называл его своим «младшим братом» и требовал от него богатых даров (Timkovskiy, 1824:42-43). П.И. Кафаров (Kafarov, 1892:38; 50), путешествовавший по Монголии четверть века спустя, также рассылал богатые дары начальникам почтовых станций, через которые должен был проезжать - сами они являться к нему не соизволяли (Kafarov, 1892:38, 50). Примечательно, что большинство чиновников не получало никакого жалования лишь продовольственное содержание; тем не менее, «по временам достойнейшим делаются подарки» (Haupt, 1858:33).

\section{НАЛОГИ, ПОВИННОСТИ И ИХ ЭВОЛЮЦИЯ}

Монголы относились к привилегированной части подданных империи Цин. Согласно запискам Е. Владыкина они стояли по статусу ниже маньчжуров, 
но неизмеримо выше китайцев-ханьцев (Bereznitsky, 2017:127). Привилегированное положение монголов было связано с их главной повинностью в пользу империи Цин - военной службой, которую они несли и непосредственно в Монголии, и в других частях империи. «Внутренняя» служба была связана с охраной границ и сопровождением иностранцев по территории Монголии под общим контролем сначала только местных правителей, а с второй половины XVIII в. - и цинских наместников (Ibid.:66). Кроме того, монгольские воины служили в разных частях Китая, в т.ч. и в столице. С. Рагузинский упоминает о монголах-найманах, которые «из жалования» служили в Пекине наряду с китайцами (Demidova, Myasnikov, 1990:207). Е. Владыкин также пишет, что в Пекине монгольская гвардия насчитывала 211 рот общей численностью 21733 чел. (Ibid.:121). С. Рагузинский упоминает о присутствии монгольских караулов и во внутренних районах Китая (Demidova, Myasnikov, 1990: 205). И.В. Якоби сообщает, что чахары были включены в маньчжурскую военную систему: «состоят под желтым знаменем» (Myasnikov, Sarkisova, 2011:205). В. Гаупту его информаторы говорили, что чахарские отряды даже участвовали в боевых действиях против «энджели», т.е. англичан (Haupt, 1858:18).

Впрочем, привилегиями пользовались лишь монголы Халхи, тогда как южные монголы (суниты и чахары) уже были в большей степени интегрированы в маньчжурское и китайское политико-правовое пространство. Это нашло отражение, в первую очередь, в возложении на них ряда повинностей, которые уже несли китайцы (Chia, 2017:170; Erdenchuluu, 2014: 49).

Как и в XVII в., в Монголии на протяжении большей части XVIII в. еще не была возрождена система почтовых станций, существовавшая в Монгольской империи и пришедшая в упадок после ее распада. Даже в 1760-е гг. дипломаты должны были менять лошадей и верблюдов и получать продовольствие либо в «урочищах», либо же, если животные уставали, просто-напросто делать длительные привалы и давать им отдых (Myasnikov, Sarkisova, 2011:294295). Однако в последней трети XVIII в. маньчжуры, стремясь упорядочить систему коммуникаций в своих владениях, начали ее восстановление - причем именно с южно-монгольских областей. И если С. Рагузинский в 1726 г. лишь упоминает о том, что на монголов-сунитов была возложена повинность по предоставлению русскому посольству подвод (Demidova, Myasnikov, 1990:207), то А. Незнаев, посетивший Кобдо в 1771 г., сообщает, что в этом регионе уже действовала четко организованная ямская система, и что он официально получал подводы и лошадей, которых ямщики должны предоставлять из собственных средств (Neznaev, 1868:298; 299).

Но уже в 1-й пол. XIX в. маньчжурские власти стали уделять значительное внимание восстановлению системы ямских почт, фактически пережившей «второе рождение» (после империи Чингис-хана). П.И. Кафаров в сер. XIX в. насчитывает 48 постоянных «военных» почтовых станций, находившихся под контролем гусай-амбаня или дутуна - военного чиновника, напрямую подчинявшегося главнокомандующему, при этом хотя станции содержали сами хал- 
хасцы, смотрителями над несколькими станциями назначались маньчжурские чиновники, сосланные в Монголию за преступления (Kafarov, 1892:51-52). Кроме того, если в Монголию прибывали особо важные чиновники из Китая или посланцы с указами о назначении князей на должность, на пути их следования могли создаваться и временные станции, ответственность за содержание которых ложилась на самих князей (Haupt, 1858:23).

Служители станций несли ямскую повинность по жребию, определявшему не только тех, кто будет работать на станции, но и срок его службы. Правда, это отнюдь не означало, что эти служащие должны содержать станции за свой счет - напротив, они получали жалование из казны за свою работу, а лошадей, верблюдов и продовольствие поставляли в качестве повинности соседние монгольские улусы. Помимо монголов к станциям в отдельных местностях (в частности в Харчине) также «приписывались» для несения повинностей т.н. хабсулга — полумонголы-полукитайцы, - которые снабжали станции просом и кунжутом, а также предоставляли коров (Kafarov, 1892:54, 61). Это также отражает политику «сбережения сил монгольского народа», поскольку впоследствии, после ее отмены, никакого жалования монгольские почтовые служащие не получали и нередко содержали станции именно за свой счет.

Чиновники, проезжавшие через станции, имели право на получение лошадей или верблюдов, продовольствия, а также «съестных денег». При этом количество продовольствия зависело от статуса проезжающего официального лица - это мог быть целый баран, половина или баранья нога; то же касалось и «съестных денег» - например битикчи, сопровождавший П.И. Кафарова, получал чин серебра (приблизительно 80 коп.) (Kafarov, 1892: 37; 55). Впрочем, сами чиновники нередко злоупотребляли своими полномочиями: в 1830 г. монголы жаловались О.М. Ковалевскому, что, проезжая через их стойбища, они требовали от них лошадей, который оставляли либо в следующем стойбище либо на ближайшей почтовой станции (Kovalevskiy, 2006:22).

Согласно сведениям российских путешественников иностранцы, даже обладающие дипломатическим статусом, на почтовых станциях не обслуживались. Так, Н.Я. Бичурин вспоминает, что еще в 1808 г. миссия была вынуждена платить по 2 чина серебра за верблюда и 1 чину за лошадь. А во время его обратной поездки в 1821 г. монголы вообще отказывались предоставлять верблюдов членам российской духовной миссии даже за деньги - лишь вмешательство маньчжурского чиновника, сопровождавшего миссию, позволило им не остаться без транспортных средств, после чего монголы были «одарены» (Вichurin, 1828: 64-65). При этом Бичурин подчеркивал, что речь идет именно об одаривании почтовых служащих, а не взимании ими платы. Е.Ф. Тимковский также вспоминал, что за предоставление верблюдов и провоз багажа сопровождаемой им миссии чиновники взимали плату, причем не фиксированную, «а соразмерно по обстоятельствам» (Timkovskiy, 1824:181). По-видимому, подобный подход монгольских почтовых служащих стал следствием политики империи Цин, которая, как отмечалось выше, в этот период времени старалась изолиро- 
вать монголов от иностранцев. Следовательно, предоставление транспорта, продовольствия и оказание иных услуг иностранцам, проезжающим через Монголию, скорее всего, воспринималось монголами как нарушение этих предписаний маньчжурских властей.

Система налогов и повинностей в Монголии специально путешественниками не исследовалась, однако и в этой сфере они зафиксировали довольно важные особенности. Прежде всего, они отмечают, что в отношении князей политика «сбережения сил монгольского народа» соблюдалась маньчжурскими властями наиболее последовательно. Во-первых, они сами не платили никаких налогов и не несли повинностей. Во-вторых, помимо того, что все налоги и сборы с собственных подданных шли в их пользу, те их них, кто имел маньчжурские придворные титулы или воинские звания, получали жалование (Віchurin, 1828:167-168; Timkovskiy, 1824:170). Кроме того, монгольские вассалы периодически доставляли дань к императорскому двору: северные князья - раз в 4 года, южные - раз в 3 года. Н.Я. Бичурин достаточно подробно характеризует эту дань, которая была «малозначаща по ее количеству, но важна по цели», т.е. свидетельствовала о признании монгольскими владетелями сюзеренитета Цин и выражении ими своей лояльности империи, обещая поддерживать его силой своего оружия. Как правило, дань была символической, зато сам император в ответ одаривал князей куда более щедро (Elverskog, 2006:70-71; Heuschert-Laage, 2014:658): за каждую лошадь, предоставленную в качестве дани, он выдавал по 10 лан серебра и два куска атласа, за барана - 10 лан серебра, за дрессированного кречета или борзую - 10 лан серебра и 4 куска атласа и т.д. (Bichurin, 1828:168).

В целом же путешественники отмечают, что монгольская знать («истинные помещики», как их характеризовал Н.Я. Бичурин) налогов не платила, тогда как остальные монголы, по сути обладавшие лишь полусвободным статусом, платили налоги своим владетелям. Кроме того, они несли «земские повинности»: содержали почтовые станции, дороги и пр., а также военную службу - сами служили в армии или же снабжали призванных в армию земляков лошадьми, продовольствием и т.д. (Bichurin, 1828:161; Kovalevskiy, 2006:18-19, 22).

О.М. Ковалевский описывает весьма интересный пример несения повинностей, по-видимому, также характерный для политики «сбережения сил монгольского народа». Речь идет о ряде семейств, которые присматривали за стадами верблюдов, лошадей, баранов, считавшихся собственностью «богдохана», т.е. маньчжурского императора. Эти семейства считались освобожденными от несения всех прочих повинностей, получали жалование 12 лан серебра в год (их начальник-дарга - 24 лана) и, кроме того, могли пользоваться шерстью баранов или верблюдов, ездить на лошадях при выполнении своих обязанностей и т.д. (Kovalevskiy, 2006:16; 28).

В число налогоплательщиков не включались рабы, полностью зависимые от хозяев, и престарелые монголы, по возрасту освобожденные от несения воинской повинности. В связи с этим при проведении переписей населения (ко- 
торые каждые три года осуществляли сеймы монгольских аймаков) эти категории не включались в ведомости, передаваемые в Палату внешних сношений (Bichurin, 1828:160). Также не платило никаких налогов монгольское буддийское духовенство. Формально оно находилось в ведении Палаты внешних сношений, причем каждый лама считался «приписанным» к той или иной кумирне, однако по согласованию шанцзотбы (управляющего Богдо-гэгэна) с хошунными начальниками они могли переселяться в улусы. При этом те, кто проживал непосредственно при монастырях, существовали за счет казны Богдо-гэгэна, а кто проживал в улусах - за счет собственных родственников (Kovalevskiy, 2006:22, 27-28), для которых их содержание становилось, по сути, еще одной повинностью.

Интеграция южных монголов в имперское пространство осуществлялась и в отношении их жизненного уклада: цинские власти всячески стремились привязать их к земле и в результате распространить на них статус китайцевземледельцев, в т.ч. и обязанность платить налоги и сборы (Atwood, 2012:10). Как отмечает академик И.Г. Георги, монголы, уже давно пребывавшие под китайским владычеством, «пришли напоследок в такое убожество, что принялись за земледелие, к которому китайцы всеми мерами их поощряют» (Georgi, 1799:39). Его коллега И.П. Фальк сообщает, что аналогичным образом маньчжуры заставили заниматься земледелием и только что покоренных ими ойратов (Fal'k, 1825:30). А в 1830-1840-е гг., согласно сведениям горного чиновника С.И. Гуляева, ойраты уже должны были содержать китайские войска, платя налог скотом и неся в пользу китайских чиновников другие повинности (Boro$\operatorname{nin}, 2003: 133)$.

С другой стороны, маньчжурские власти не были заинтересованы в окончательном обеднении своих монгольских подданных — что, к тому же, как уже отмечалось, могло привести и к их восстаниям против империи Цин. Поэтому время от времени наиболее бедным родам и аилам предоставлялась возможность несколько повысить свое благосостояние. В частности, С. Рагузинский упоминает, что монголам, у которых были «самые убогие юрты», было дано разрешение добывать соль и возить ее в Китай на продажу (Demidova, Myasnikov, 1990:207).

В отношении же монголов Халхи маньчжурские власти периодически вводили экстраординарные сборы и повинности - как правило, в связи с военными кампаниями. Так, главный пограничный управитель в Забайкалье И.Д. Бухгольц на основе сведений, полученных от информаторов, сообщал в Коллегию иностранных дел в 1729 г., что после неудач в войне с Джунгарией цинские власти ввели огромные поборы с монголов для содержания войск в пограничных крепостях, что полностью противоречило прежним налоговым иммунитетам и заставляло монголов подумывать о бегстве в пределы России (Andrievich, 1887:152). Курьер В.Ф. Братищев, ездивший в Пекин через Монголию в 1757 г., также сообщает, что монголы буквально были разорены сборами в связи с очередной войной империи Цин против джунгар (Myasnikov, Sarkisova, 2011:201- 
202). В связи с этим существенно уменьшилось количество перебежчиков «ясачных» из российских владений в Монголию, поскольку они «боятся... от китайцов и мунгальцов лишних запросов» (Demidova, Myasnikov, 1990:388).

Русские путешественники упоминают монгольских торговцев (Demidova, Myasnikov, 1990:213), однако сведения об их деятельности дают основание считать, что маньчжурские власти всячески старались ограничивать это направление деятельности своих монгольских вассалов - особенно торговые операции с иностранцами. Так, цинские власти запрещали российским купцам приезжать в Китай без специальных «паспортов», и монгольские правители на основании этого запрета задерживали их в своих владениях, хотя сами же страдали от отсутствия возможности вести с ними торговлю (Andrievich, 1887:133). Нередко китайские власти вводили в отношении российских торговцев своего рода «экономические санкции» по политическим причинам, и монголы были вынуждены вести себя соответственно. Так, С. Писарев, кацелярист при посольстве С. Рагузинского, упоминает, что монгольские власти Урги запретили русским купцам вести торговлю, пока не будет решен вопрос между двумя империями о перебежчиках (Demidova, Myasnikov, 1990:514). Отсутствие в Монголии развитой торговли подчеркивалось даже отсутствие механизма взимания торговых сборов и пошлин в монгольских землях: первые такие сборы российские путешественники уплачивали в Калгане - непосредственно на границе с китайскими владениями (Bereznitsky, 2017:15).

Таможенные пошлины в рассматриваемый период маньчжуры сохраняли за собой - так, по сведениям Н.Я. Бичурина, в г. Калган в Чахаре имелась таможня, подведомственная «корпусному генералу» (Bichurin, 1828:30). Это также полностью вписывалось в систему контроля и ограничения контактов монголов с иностранцами - в т.ч. и в торговой сфере. Безусловно, монгольским подданным империи Цин это было крайне невыгодно, и они старались использовать любую возможность, чтобы обходить такие запреты. Например, Е.Ф. Тимковский сообщает, что как только сопровождаемая им миссия пересекла границу, монгольские «пограничники» тут же попытались организовать торговлю с ее представителями и продать ей лошадей; аналогичные попытки предпринимали также один тайджи и один «монгольский помещик», через владения которых проезжала миссия (Timkovskiy, 1824:19-20, 190, 191).

Впрочем, и сама торговля, как отмечают путешественники, в Монголии не была развитой, имея в большей степени характер натурального обмена (лишь в Урге расплачивались кирпичным чаем как эквивалентом денег). Необходимые товары монголы, таким образом, могли приобретать за скот, шкуры диких животных, овчины, молочные продукты - но такие товары требовались китайским торговцам, тогда как российские регионы, пограничные с Монголией и сами были богаты ими (Bichurin, 1828:154-155). Таким образом, есть основания полагать, что развитие товарно-денежных отношений в Монголии также могло искусственно запрещаться китайскими властями все с той же целью изоляцией монголов от внешних контактов. 
Путешественники 1-й пол. XIX в. отмечают существенные различия в правовом статусе населения различных регионов Монголии. Так, чахары, раньше других монголов примкнувшие к маньчжурам и снискавшие за свою поддержку немалые льготы, вели себя дерзко и вызывающе не только в отношении других монголов, но и иностранцев, а также позволяли себе не подчиняться даже маньчжурским чиновникам. Так, О.М. Ковалевский отмечает, что почтовые служащие в Чахаре отказывались выполнять приказы сопровождавшего его маньчжура-битикчи, заявляя, что следуют распоряжениям лишь собственного начальства (Kovalevskiy, 2006:27). Халхасцы, несшие пограничную охрану и составлявшие в течение длительного времени основную конную силу империи Цин, также обладали определенным количеством льгот - в частности, вышеупомянутым освобождением от налогов в императорскую казну. А жившие между северными и южными монголами суниты, напротив, являлись самыми бесправными жителями Монголии, которых притесняли и местная знать, и маньчжуры, не предоставляя никаких льгот и привилегий. Так, когда русская духовная миссия, сопровождаемая Е.Ф. Тимковским, прошла Халху и вошла в улусы сунитов, последним пришлось сопровождать ее не только без всякого вознаграждения, но и питаться в пути за собственный счет (Timkovskiy, 1824:250-251). В сравнительно же недавно покоренной Джунгарии, помимо собственно монголов, проживало немало китайцев - крестьян, занимавшихся земледелием в этих опустевших районах, ссыльных, военных поселенцев (Bichurin, 1828:151).

\section{ПРЕСТУПЛЕНИЯ, НАКАЗАНИЯ И ОТНОШЕНИЕ К НИМ В РАЗНЫХ РЕГИОНАХ МОНГОЛИИ}

Из особенностей правового статуса разных регионов Монголии, повидимому, вытекало и разное отношение их жителей к различным видам противоправных деяний. Так, среди халхасцев была распространена практика грабительских набегов на соседей, что расценивалось как геройство (Bichurin, $1828: 170)^{3}$. Е.Ф. Тимковский описывал, как у него на глазах один лама (!) украл кузнечный инструмент и умчался на коне в степь, где его так и не сумели настичь (Timkovskiy, 1824:220). Чахары же проявляли больше склонности к кражам, особенно у чужаков (в т.ч. и иностранцев, включая членов русских миссий), не считая свои действия преступлением. Как отмечал О.М. Ковалевский, в их глазах «воровство также не есть порок в мнении цахара, но искусство пользоваться неосторожностью ближнего» (Kovalevskiy, 2006:30).

Весьма показательно отражение незначительности полномочий монгольских властей в обеспечении безопасности и рассмотрении дел об уголовных

\footnotetext{
${ }^{3}$ В данном случае уместно провести параллель с казахской «барымтой» — набегом с целью угона: казахи считали участников таких набегов героями, однако российская администрация объявила барымту преступлением и преследовала в уголовном порядке (Martin, 1997).
} 
преступлениях. Особенно частыми были дела о конокрадстве, которое у кочевников-монголов, безусловно, являлось одним из самых распространенных преступлений и в XVIII в. При этом неоднократно их жертвами становились и русские дипломаты, которые не только лишались лошадей и верблюдов, но и подвергались грабежу и насилию. Например, в 1745 г. торговый караван Г.К. Лебратовского подвергся нападению грабителей, причем пострадали даже члены его семьи (Bereznitsky, 2017:86), хотя представители России неоднократно жаловались цинским властям на подобные действия их монгольских подданных и требовали, чтобы эти жалобы рассматривались маньчжурскими чиновниками (поскольку по законодательству империи Цин конокрадство наказывалось смертной казнью). Однако маньчжуры полностью перепоручали разбирательство подобных дел монгольским правителям, которые, как неоднократно докладывал И.В. Якоби, неоднократно ездивший в Пекин в качестве курьера в 1750-е гг., чаще всего не только не казнили преступников, но нередко и сами укрывали их. Влиятельнейший из монгольских правителей Тушету-хан вообще ограничивался лишь обещанием удерживать своих подданных от конокрадства в дальнейшем (Andrievich, 1887:178; 210; 212).

В связи с все большей интеграцией в цинское правовое пространство борьба с преступлениями в Монголии 1-й пол. XIX в. активизировалась, о чем свидетельствуют и российские путешественники. В частности, сурово преследовались должностные преступления (действия или бездействие) - в тех случаях, когда они приносили вред императору или самим монгольским правителям (Erdenchuluu, 2014:51-52). Так, Е.Ф. Тимковский описывает случай, когда цзангин (командир эскадрона), допустивший беспорядки и воровство в своих владениях, был оштрафован на 27 лан серебра и вынужден подать в отставку. Любопытно, что простые монголы склонны были оправдывать нарушителя, объясняя причину беспорядков тем, что он мог уследить лишь за своими непосредственными подчиненными, но не за остальным населением вверенного ему улуса: «а как усмотреть... - степь велика» (Timkovskiy, 1824:204-205).

Строгое наказание грозило за халатное отношение к стадам императора или монгольских дзасаков. Если за хороший приплод пастухи могли рассчитывать на вознаграждение, то в случае уменьшения поголовья следовали неотвратимые наказания. Если количество скота убывало в соотношении 1 к 10, пастушеские начальники лишались части жалования, а простых пастухов подвергали порке, если же урон скота составлял 2 к 10, то начальников лишали половины жалования, а также все пастухи обязаны были возместить потери за счет собственного скота - до 5 голов с человека (Kovalevskiy, 2006:16).

Среди наказаний также присутствовали высылка преступников и их обращение в рабство - в частности, тех, кто предпочитал остаться в родных улуcax, пусть даже и несвободным, а не отправляться на чужбину. При этом лишение свободы за преступление могло распространяться и на все семейство преступника (Bichurin, 1828:161-162). Правда, путешественники не уточняют, за какие именно преступления предусматривалось столь суровое наказание. 
Исследователи делают несколько кратких, но немаловажных замечаний относительно организации суда в Монголии, из которых можно сделать вывод, что в этой сфере правоотношений монголы продолжали сохранять значительную степень автономности. Формально каждый монгольский владетельный князь являлся судьей над своими подданными, более серьезные преступления разбирал аймачный сейм (являвшийся также апелляционной инстанцией в отношении решений князей), и только в исключительных случаях дела (о самых опасных преступлениях) передавались уже в Палату внешних сношений (Bichurin, 1828:167). П.И. Кафаров упоминает о присутствии в Монголии маньчжурских судей - при наиболее важных почтовых станциях (Kafarov, 1892:82), но ничего не говорит об их компетенции: скорее всего, она распространялась на вышеупомянутых китайских чиновников, сосланных в Монголию и служивших на тех же станциях.

Малозначительные же дела монголы предпочитали решать путем досудебного «мирового соглашения», совершенно обоснованно считая, что в таком случае понесут гораздо меньше убытков. О.М. Ковалевский описывает подобную ситуацию, свидетелем которой стал сам: один служитель битикчи обидел чиновника, который пригрозил, что пожалуется начальству; битикчи поспешно приказал своему служителю извиниться перед чиновником и поднести ему табаку, что и было сделано (Kovalevskiy, 2006:17).

\section{ОСОБЕННОСТИ СЕМЕЙНЫХ ПРАВООТНОШЕНИЙ}

Семейные правоотношения у монголов также интересовали российских путешественников 1-й пол. XIX в., учитывая, что большинство авторов анализируемых нами трудов являлись представителями духовенства - а ведь церковь в России, как известно, довольно долго сохраняла монополию на регулирование семейно-правовых отношений и надзор за нравственностью супругов. В связи с этим весьма показательным является замечание Н.Я. Бичурина, что монгольские женщины «мало уважают непорочность ложа» (Bichurin, 1828:170; Rabinovich, 2014:79; Kovalevskiy, 2006:22) ${ }^{4}$.

Тот же Н.Я. Бичурин (1828:182) отмечает и существовавший у монголов запрет жениться на представительницах своего рода по мужской линии, при этом двоюродные родственники - сын брата и дочь сестры (или наоборот) вполне могли сочетаться браком. Также отмечается распространенность среди монголов обычая договариваться о браке даже новорожденных детей. А для официального заключения брака требовалось, во-первых, согласовать «астрологические знаки» (т.е. гороскоп) жениха и невесты, подходят ли они друг другу, во-вторых, внести выкуп (аналог калыма). Правда, гороскопы заказывали, как

\footnotetext{
${ }^{4}$ Как известно, архимандрит Иоакинф и сам не слишком ревностно соблюдал обет безбрачия, за что в свое время даже подвергался наказанию.
} 
правило, знатные и состоятельные люди, простые же монголы обходились без этой формальности. При этом очень часто жених впервые видел невесту уже на свадьбе (Bichurin, 1828:182-183; Kovalevskiy, 2006:22).

Н.Я. Бичурин также приводит интересное наблюдение: еще в XVII в. у монголов формально существовало многоженство, и лишь маньчжуры постепенно ввели единоженство, т.е. законной являлась лишь одна жена, остальные имели статус наложниц (Bichurin, 1828:185). Этот китайский обычай, надо полагать, был введен с целью уменьшить число возможных наследников улусов, титулов и воинских званий и, соответственно, более эффективного контроля над монгольской знатью.

В. Гаупт отмечает на основе общения с монголами, что женщины полностью вели все домашнее хозяйство, включая установку юрт, уборку, шитье одежды и пр., тогда как мужчины только пасли скот и несли службу (Haupt, 1858:15-16).

\section{ЗАКЛЮЧЕНИЕ}

Проведенный анализ источников позволяет сделать вывод, что правовая ситуация в частях Монголии, с конца XVII в. находившихся под контролем маньчжуров, не может быть охарактеризована как «развитие». Маньчжуры не нуждались в сильной и развитой Монголии, власти которой могли бы самостоятельно определять свою дальнейшую судьбу — им была необходима лишь многочисленная монгольская конница, обеспечивавшая охрану границ - особенно во время противостояния империи Цин с Джунгарским ханством (Demidova, Myasnikov, 1990:397) и участвовавшая в цинских завоевательных кампаниях. Поэтому китайские власти взяли курс на «консервацию» монгольского общества, стараясь всячески удерживать его на прежнем уровне развития и не допуская никаких попыток модернизации. Это достигалось запретами контактов монгольских властей с иностранными государствами, ограничением торговой деятельности монголов. Монгольское законодательство оставалось весьма консервативным, и новые направления правоотношений как правило регулировались либо специальным маньчжурским правом для монголов («Уложение Китайской палаты внешних сношений»), либо непосредственными распоряжениями полномочных представителей Цин в Монголии - наместников, власть которых в течение XVIII - 1-й пол. XIX в. неуклонно возрастала. Своеобразной «компенсацией» за ограничения поначалу было сохранение за монгольскими феодалами полноты власти над своими подданными и освобождение от уплаты налогов в имперскую казну, но со временем и в этой сфере льготы все больше и больше сокращались. Как представляется, российским современникам в достаточной степени удалось отразить переходный статус Монголии в составе империи Цин - от достаточно привилегированного положения в рамках политики «сбережения сил монгольского народа» XVIII в. до постепенной интеграции Монголии в состав Китая в качестве его неотъемлемой части. 
Сами российские путешественники, несмотря на постепенное подчинение монголов маньчжурам, по-прежнему с вниманием относились к особенностям их политико-правового положения, которые могли иметь важное значение при выстраивании отношений русских с монголами в дальнейшем. За редкими исключениями путешественники не критикуют монгольские правовые нормы и правоотношения, не оценивают их как неразвитые, ограничиваясь описанием их действия на практике, а также демонстрируют свою готовность адаптироваться к ним для выстраивания с монголами конструктивных отношений. В этом, как представляется, проявилось следование сторонникам сложившемуся и в европейской антропологической науке к XVIII в., которые которого признавали равенство различных культур и, соответственно, правовых систем, не деля их на «высшие» и «низшие», «развитые» и «примитивные» (Brummet, 2009:33) ${ }^{5}$. Безусловно, вряд ли российские путешественники (большинство из которых были все же не учеными, а дипломатами, военными и миссионерами) были в курсе антропологических тенденций и сознательно следовали этому принципу - просто иной подход в отношении к монгольским правовым традициям не позволил бы им достичь целей своих поездок. Вместе с тем многолетний (и даже многовековой) опыт взаимодействия русских с народами Сибири, чья правовая система во многом была сходна с монгольской, также способствовал восприятию монгольского права как объективной реальности, в результате чего русские путешественники не пытаясь их как-то критиковать или, тем более, адаптировать под собственные правовые взгляды и представления ${ }^{6}$.

\section{БИБЛИОГРАФИЧЕСКИЙ СПИСОК / REFERENCES}

Atwood, C.P. (2012) Banner, Otog, Thousand: Appanage Communities as the Basic Unit of Traditional Mongolian Society. Mongolian Studies, No 34, 1-76.

Andrievich, V.K. (1887) Kratkii ocherk istorii Zabaikal'ya ot drevneishikh vremen do 1762 goda [A brief outline of the history of Transbaikalia from ancient times to 1762]. SaintPetersburg: Military Printing House Publ. (in Russian).

Андриевич B.К. Краткий очерк истории Забайкалья от древнейших времен до 1762 года. СПб.: Военная типография, 1887. 249 с.

Bereznitsky, S.V. (2017) Karavannaya torgovlya Rossii s Kitaem i otechestvennaya nauka XVIII v. [Caravan trade of Russia with China and Russian science of $18^{\text {th }}$ c.]. Saint-Petersburg: MAE RAN Publ. (in Russian).

Березницкий C.B. Караванная торговля России с Китаем и отечественная наука XVIII в. СПб.: МАЭ РАН, 2017. 266 с.

\footnotetext{
${ }^{5}$ В современной юридической антропологии этот принцип трансформировался в концепцию правового плюрализма (Bocharov, 2013:116-117; Kovler, 2002:9-10; Rouland, 2000:49).

${ }^{6}$ Следует отметить, что и в дальнейшем в российской юридической антропологии именно такой подход продолжал оставаться основополагающим - даже в тот период, когда на Западе ее представители нередко становились на позиции теории «иерархии рас», «колониальной антропологии», «ориентализма» и т.д. (Klein, 2014:84; Rouland, 2000:17-18).
} 
Bichurin, N.Ya. (1828) Zapiski o Mongolii, sochinennye monakhom Iakinfom [Notes on Mongolia written by the monk Iakinf]. Vol. I. Pt. I-II. Saint-Petersburg: Tipografiya K. Krayya Publ. (in Russian).

Бичурин Н.Я. Записки о Монголии, сочиненные монахом Иакинфом. Т. I. Ч. I-II. СПб.: Типография К. Крайя, 1828. 613 с.

Boronin, O.V. (2003) Iz neopublikovannogo naslediya S.I. Gulyaeva: «Zamechanie o kitayskoy granitse pri vershinakh reki Irtysha i ob udobnosti torgovli v sey chasti» [From unpublished heritage of S.I. Gulyaev: "Notice on the Chinese border at upper river of Irtysh and convenience of trade here"]. Central Asia and Siberia. The first scientific readings of the memory of E.M. Zalkinda. May 14, 2003. Barnaul: Altai State University Publ. 130 141. (in Russian).

Боронин О.В. Из неопубликованного наследия С.И. Гуляева: «Замечание о китайской границе при вершинах реки Иртыша и об удобности торговли в сей части» // Центральная Азия и Сибирь. Первые научные чтения памяти Е.М. Залкинда. 14 мая 2003 г. Барнаул: Алтайский государственный ун-т, 2003. С. 130-141.

Bocharov, V.V. (2013) Nepisaniy zakon. Antropologiya prava [Unwritten statute. Anthropology of law]. Saint-Petersburg: Academy of Cultural Studies Publ. (in Russian).

Бочаров B.B. Неписаный закон. Антропология права. СПб.: Академия исследований культуры, 2013. 328 с.

Brummet, P. (ed.) (2009) The Book of Travels: Genre, Ethnology and Pilgrimage, 1250-1700. Leiden; Boston: Brill Publ.

Butler, W.E. (1982) The Mongolian Legal System: Contemporary Legislation and Documentation. Hague: Martinus Nijhoff Publishers Publ.

Chia, N. (2017) Lifanyuan and Libu in the Qing Tribute System. In: D. Schorkowitz and Ch. Ning, eds. Managing Frontiers in Qing China: The Lifanyuan and Libu Revisited. Leiden; Boston: Brill Publ. 144-184.

Demidova, N.F., Myasnikov, V.S. (eds.) (1990) Russko-kitayskie otnosheniya v XVIII veke [RussianChinese relations in $18^{\text {th }}$ century], vol. 2. 1725-1727. Moscow: Nauka Publ. (in Russian).

Русско-китайские отношения в XVIII веке. Т. II. 1725-1727 / Ред. Н.Ф. Демидова, В.С. Мясников. М.: Наука, 1990. 669 с.

Elverskog, J. (2006) Our Great Qing. The Mongols, Buddhism and the State in Late Imperial China. Honolulu: University of Havai'i Press Publ.

Erdenchuluu, Kh. (2014) The Study of Mongolian Legal History: new Approaches on the Basis of Local Documents. Cultural heritage of the Mongols: manuscript and archival collections in St. Petersburg and Ulaanbaatar. The international conference. April 19-20, 2013, SaintPetersburg. S. Chuluun, I.V. Kul'ganek (eds.). Ulaanbaatar; Saint-Petersburg, 40-53.

Erdenchuluu, Kh. (2014) The Study of Mongolian Legal History: new Approaches on the Basis of Local Documents. Cultural heritage of the Mongols: manuscript and archival collections in St. Petersburg and Ulaanbaatar. The international conference. April 19-20, 2013, SaintPetersburg. S. Chuluun, I.V. Kul'ganek (eds.). Ulaanbaatar; Saint-Petersburg, 40-53.

Культурное наследие монголов: рукописные и архивные собрания СанктПетербурга и Улан-Батора. Материалы международной конференции 19-20 апреля, 2013. Санкт-Петербург / Ответственный редактор С. Чулуун, Научный редактор, составитель И.В. Кульганек. СПб. Улан-Батор, 2014. С. 40-53.

Fal'k, I.P. (1825) Polnoe sobranie uchenykh puteshestviy po Rossii, izdavaemoe Imperatorskoy Akademiey nauk. T. VII. Dopolnitel'nye stat'i po zapiskam puteshestviya akademika Fal'ka [Complete collection of scientific journeys on Russia published by Imperial Academy of Sciences. T. VII. Additional articles to notes of journey of academician Fal'k]. Saint-Petersburg: Imperial Academy of Sciences Publ. (in Russian). 
Фальк И.П. Полное собрание ученых путешествий по России, издаваемое Императорской Академией наук. T. VII. Дополнительные статьи по запискам путешествия академика Фалька. СПб.: Императорская Академия наук, 1825. 233 с.

Georgi, I.G. (1799) Opisanie vsekh v Rossiyskom gosudarstve obitayushchikh narodov, takzhe ikh zhiteyskikh obryadov, ver, obyknoveniy, zhilishch, odezhd i prochikh dostopamyatnostey. Chast' chetvertaya o narodakh mongol'skikh, ob armyanakh, gruzinakh, indiytsakh, nemtsakh, polyakakh i o vladychestvuyushchikh rissiyanakh s opisaniem vsekh imenovaniy kozakov, takzhe Istoriya o Maloy Rossii i kupno i Kurlyandii i Litve [Description of all peoples inhabited Russian state as well as their everyday rites, religions, customs, dwellings, clothes and other memorabilities. The forth part on Mongol, Armenian, Georgian, Indian, German, Polish peoples, title nation of Russians with description of Cossacks of all names as well as history of Russia Minor, Kurlyandia and Lithuania]. Saint-Petersburg: Imperial Academy of Sciences Publ. (in Russian).

Георги И.Г. Описание всех в Российском государстве обитающих народов, также их житейских обрядов, вер, обыкновений, жилищ, одежд и прочих достопамятностей. Часть четвертая о народах монгольских, об армянах, грузинах, индийцах, немцах, поляках и о владычествующих риссиянах с описанием всех именований козаков, также История о Малой России и купно и Курляндии и Литве. СПб.: Императорская Академия наук, 1799. 446 с.

Haupt, V. (1858) Zametki na puti iz Kyakhty v Urgu v 1850 godu [Notes on the way from Kyakhta to Urga in 1850]. Zapiski Sibirskogo otdela Imperatorskogo russkogo geograficheskogo obshchestva. Kn. 5 [Notes of the Siberian Department of the Imperial Russian Geographical Society. Vol. 5]. 1-100. (in Russian).

Гаупт В. Заметки на пути из Кяхты в Ургу в 1850 году // Записки Сибирского отдела Императорского русского географического общества. Кн. 5. 1858. С. 1-100.

Heuschert-Laage, D. (2014) From Personal Network to Institution Building: The Lifanyuan, Gift Exchange and the Formalization of Manchu-Mongol Relations. History and Anthropology. 25, (5), 648-669. DOI: 10.1080/02757206.2014.946022.

Kafarov, P.I. (1892) Dnevnik o. ierodiakona Palladiya, vedenniy vo vremya pereezda po Mongolii v 1847 g. [Diary of travel on Mongolia in 1847 by hierodeacon Palladiy] Zapiski Imperatorskogo Russkogo geograficheskogo obshchestva po obshchey geografii [Notes of the Imperial Russian Geographical Society on General Geography] vol. 22, No. 1, 37-99. (in Russian).

Кафаров П.И. Дневник о. иеродиакона Палладия, веденный во время переезда по Монголии в 1847 г. // Записки Императорского Русского географического общества по общей географии. Т. XXII. № 1. С. 37-99.

Kleyn, L. (2014) Istoriya antropologicheskikh ucheniy [History of anthropological studies]. SaintPetersburg.: Publishing House of St. Petersburg University Publ. (in Russian).

Клейн Л. История антропологических учений. СПб.: Изд-во Санкт-Петербургского ун-та, 2014. 744 с.

Kovalevskiy, O.M. (2006) Rossiya - Mongoliya - Kitay: Dnevniki mongoloveda O.M. Kovalevskogo 1830-1831 gg. [Russia - Mongolia - China: diaries of Mongolist O.M. Kovalevskiy of 1830-1831], publ., intr., glossary, comments and index by R.M. Valeev, I.V. Kul'ganek. Kazan: “Taglimat” IEUP Publ. (in Russian).

Ковалевский О.М. Россия - Монголия - Китай: Дневники монголоведа О.М. Ковалевского 1830-1831 гг. / Подгот. к изд., пред., глоссарий, коммент. и указ. Р.М. Валеева, И.В. Кульганек. Казань: «Таглимат» ИЭУП, 2006. 103 с.

Kovler, A.I. (2002) Antropologiya prava: Uchebnik dlya vuzov [Anthropology of law; Textbook for institutes of higher education]. Moscow: Norma Publ. (in Russian).

Ковлер А.И. Антропология права: Учебник для вузов. М.: Норма, 2002. 480 с. 
Martin, V. (1997) Barymta: Nomadic Custom, Imperial Crime. In: D. Brower, E.J. Lazzerini (eds.). Russia’s Orient: Imperial Borderlands and Peoples, 1750-1917. Bloomington: Indiana University Press Publ., 249-270.

Myasnikov, V.S., Sarkisova, G.I. (eds.) (2011) Russko-kitayskie otnosheniya v XVIII veke [Russian-Chinese relations in $18^{\text {th }}$ century], vol. 6. 1752-1765. Moscow: Pamyatniki istoricheskoy mysli. (in Russian).

Русско-китайские отношения в XVIII веке. T. VI. 1752-1765 / Ред. В.С. Мясников, Г.И. Саркисова. М.: Памятники исторической мысли, 2011. 427 с.

Neznaev, A. (1868) Poezdka Arefiya Neznaeva v Khobdo v 1771 g. Soob. P.A. Gel'mersenom [A trip of Arefiy Neznayev to Hobdo in 1771 / Coll. P.A. Gelmersen]. Izvestiya Imperatorskogo Russkogo geograficheskogo obshchestva, T. IV., 293-300. (in Russian).

Незнаев А. Поездка Арефия Незнаева в Хобдо в 1771 г. / Сооб. П.А. Гельмерсеном // Известия Императорского Русского географического общества. T. IV. 1868. С. 293-300.

Pallas, P.S. (1788) Puteshestvie po raznym provintsiyam Rossiyskogo gosudarstva. Per. V. Zueva [Travel of different provinces of the Russian state, transl. by V. Zuyev]. Pt. 3, ${ }^{\text {st }}$ half. Saint-Petersburg: Imperial Academy of Sciences Publ. (in Russian).

Паллас П.С. Путешествие по разным провинциям Российского государства / Пер. В. Зуева. Ч. 3. Пол. 1-я. СПб.: Императорская Академия наук, 1788. XVI. 624 с.

Popov, A.V. (2015) Qing legislation of $18^{\text {th }}$ - first half of $19^{\text {th }}$ c. on "economy of forces of the Mongol people". In: International conference "Z.K. Kazyanenko - treacher and mongolist" (devoted to her $90^{\text {th }}$ birthday. St. Petersburg, September 30 - October 1, 2015. Programme. Abstracts. Saint-Petersburg: IVR RAN, 27-38. (in Russian).

Попов A.B. Цинское законодательство XVIII - первой половины XIX в. о «сбережении сил монгольского народа» // Международная конференция «3. К. Касьяненко - Учитель и монголовед (посвящается 90-летию). 30 сентября - 1 октября 2015 г., Санкт-Петербург. Программа. Тезисы. СПб.: ИВР РАН, 2015. С. 27-38.

Rabinovich, E.I. (2014) «Prelestnye vsadnitsy bez robosti pod'ezzhali k nam»: seksual'naya kul'tura mongol'skikh narodov v zapiskakh russkikh puteshestvennikov XIX veka ["Charming horsewomen ride to us without shyness": sexual culture of Mongol peoples in notes of Russian travelers of $19^{\text {th }}$ century]. In: Russia and Orient: cultural connections in the past and present: material of International scientific conference $\left(9^{\text {th }}\right.$ Kolosnitsyn readings). April 16-17, 2014. Ekaterinburg: University of Humanities Publishing House Publ., 7884. (in Russian).

Рабинович Е.И. «Прелестные всадницы без робости подъезжали к нам»: сексуальная культура монгольских народов в записках русских путешественников XIX века // Россия и Восток: культурные связи в прошлом и настоящем: материалы Международной научной конференции (IX Колосницынские чтения), 16-17 апреля 2014 г. Екатеринбург: Изд-во Гуманитарного университета, 2014. С. 78-84.

Rouland, N. (2000) Yuridicheskaya antropologiya. Uchebnik dlya vuzov [Legal anthropology. Textbook for institutes of higher education], transl. V.S. Nersesyants (ed.). Moscow: Norma Publ. 2000. (in Russian).

Рулан Н. Юридическая антропология. Учебник для вузов / Пер. с фр. под ред. B.C. Нерсесянца. М.: Норма, 2000. 310 с.

Tikhvinskii, S.L. (ed.) (1978) Russko-kitayskie otnosheniya v XVIII veke [Russian-Chinese relations in $18^{\text {th }}$ century], vol. 1. 1700-1725. Moscow: Nauka Publ. (in Russian).

Русско-китайские отношения в XVIII веке. Т. I. 1700-1725. Документы и материалы / Ред. Тихвинский, С.Л. М.: Наука, 1978. 704 с.

Timofeev, A.I. (1885) Pamyatniki sibirskoy istorii XVIII veka [Monuments of Siberian history of $18^{\text {th }}$ century], vol. II: 1713-1724. Saint Petersburg: Printing house of the Ministry of the Interior Publ. (in Russian). 
Тимофеев А.И. Памятники сибирской истории XVIII века. Кн. II: 1713-1724. СПб.: Типография Министерства внутренних дел, 1885. 585 с.

Timkovskiy, E. (1824) Puteshestvie v Kitai cherez Mongoliyu v 1820 i 1821 godakh [Journey to China through Mogolia in 1820 and 1821], pt. 1. Saint-Petersburg: Printing House of the Medical Department of the Ministry of the Interior Publ. (in Russian).

Тимковский Е. Путешествие в Китай через Монголию в 1820 и 1821 годах. Ч. 1. Переезд до Пекина. СПб.: Типография Медицинского департамента Министерства внутренних дел, 1824. $411 \mathrm{c}$.

Zhang, Y. (2017) The Libu and Qing Perception, Classification and Administration of Non-Han

People. In: D. Schorkowitz and Ch. Ning, eds. Managing Frontiers in Qing China: The Lifanyuan and Libu Revisited. Leiden; Boston: Brill Publ., 116-143.

\title{
Об авторе:
}

Почекаев Роман Юлианович - кандидат юридических наук, доцент, профессор, заведующий кафедрой теории и истории права и государства, юридический факультет, Национальный исследовательский университет «Высшая школа экономики» - СанктПетербург

ORCID ID: 0000-0002-4192-3528

e-mail:rpochekaev@hse.ru

\section{Для цитирования:}

Почекаев Р.Ю. Правовые реалии Монголии XVIII - 1-й пол. XIX в. глазами российских путешественников (опыт юридико-антропологического анализа) // Вестник Российского университета дружбы народов. Серия: Юридические науки. 2019. Т. 23 №. 4. C. 602-621. DOI: 10.22363/2313-2337-2019-23-4-602-621.

Дата поступления в редакиию: 24 июня 2019 г.

Дата принятия к печати:15 октября 2019 г.

Research Article

\section{LEGAL REALITIES OF MONGOLIA IN $18^{\text {th }}-$ FIRST HALF OF $19^{\text {th }} \mathrm{C}$. AS SEEN BY RUSSIAN TRAVELERS (ATTEMPT OF ANALYSIS FORM LEGAL ANTHROPOLOGY POINT OF VIEW)}

\author{
Roman Yu. Pochekaev \\ National Research University Higher School of Economics \\ 17, Industrial str., 198099, St. Petersburg, Russia
}

The article is devoted to analysis of notes of Russian travelers to Mongolia as a source on legal situation in this country during $18^{\text {th }}$ - first half of $19^{\text {th }} \mathrm{c}$. Until now these texts were used mainly as a source on political or economic history as well as on ethnology of Mongols but far less as one on legal history of this people. Indeed, the information on legal realties of Mongolia is rather fragmentary and lapidary as the travelers didn't have a goal to describe state and law of Mongolia. Nevertheless, this information is of great interest and value as it allows us to give a notion on real legal situation, legal relations realized in practice - in contrast to survived written legal monuments 
(codes) of Mongols from this period: travelers could observe such legal practice and even participate in the legal relations among Mongols.

The source base of research are notes of travelers who visited Mongolia since the beginning of the $18^{\text {th }}$ c. to $1850 \mathrm{~s}$. There were diplomats (ambassadors and their companions), couriers, intelligence officers, tradesmen and scientists. Depending on goals and objectives of their trips they interested in different aspects of Mongolian legal realties, so the comparative analysis of their information allows to present different aspects of legal life of Mongols

The study of travelers' notes from the legal anthropology point of view (basing on works of N. Rouland, A.I. Kovler, V.V. Bocharov) presumes analysis positions of their authors, reasons of their interest to specific field of law as well as Mongols' attitude to law and order, legal rules, will of Mongol and Manchu authorities, etc.

Analysis of Russian travelers' notes in combination with legal monuments allow to understand better specific features in legal development of Mongolia in the turning-point period of its history: just at this time there was activated the policy of the Qing Empire to transform Mongols from autonomous vassals to complete subjects with disfranchisement, performance of duties and obligations and further closing in status with other categories of subjects (as Chinese, etc.).

Also these notes are examples of basic stage of Russian practical-oriented legal anthropology which differed from the western one by attempting to study and understand the law of "traditional" societies without disregard of the Europocentrism.

Key words: traditional law of nomadic peoples, legal anthropology, travelers' notes, Mongolia of $18^{\text {th }}-19^{\text {th }}$ cc., Qing Empire

Funding information. The research is executed at the expense of a grant of the Russian Science Foundation (project No. 19-18-00162) in the Leo Tolstoy Institute of Languages and Cultures.

\section{About author:}

Roman Yu. Pochekaev - Candidate of Legal Sciences, Associate professor, Professor, Head of the Department of Theory and History of Law and State, Law Faculty, National Research University Higher School of Economics, St. Petersburg

ORCID ID: 0000-0002-4192-3528

e-mail: rpochekaev@hse.ru

\section{For citation:}

Pochekaev, R.Yu. (2019) Legal realities of Mongolia in 18th - first half of 19th c. as seen by russian travelers (attempt of analysis form legal anthropology point of view). RUDN Journal of Law. 23 (4), pp. 602-621. DOI: 10.22363/2313-2337-2019-23-4-602-621.

Article received June 24, 2019

Article accepted October 15, 2019 